\title{
Demography factors influencing Indonesian general knowledge on COVID-19
}

\author{
Violantina Linardi ${ }^{1}$, Rizma Adlia Syakurah ${ }^{2}$, Jesica Moudy ${ }^{1}$ \\ ${ }^{1}$ Medical Profession Students, Faculty of Medicine, Sriwijaya University, Indonesia \\ ${ }^{2}$ Public Health Faculty, Sriwijaya University, Indonesia
}

\section{Article Info \\ Article history:}

Received Jun 10, 2020

Revised Nov 28, 2020

Accepted Jan 4, 2021

\section{Keywords:}

COVID-19

Demography factors

Preventive knowledge

\begin{abstract}
Pandemic COVID-19 is a health problem that is spread all over the world including Indonesia. As 4 June 2020, Indonesia has reached 28,818 persons confirmed COVID-19, 1,721 deaths related to COVID-19 and 8.892 patients have recovered from the disease. The amount of response and attention of the public regarding the COVID-19 case in Indonesia and the circulation of information in the community became the basis of interest in identifying and analyzing demography factors with general knowledge on COVID-19. Participants were 1,254 collected through online questionnaire distributed on social media platform, from February 5, 2020 to June 6, 2020. Data analyzed used Chi square test with significant $<0.05$. The result showed that majority of respondents have good general knowledge about COVID-19 and the personal prevention towards the disease $(>75 \%)$. Nonetheless, most misinformation was that COVID-19 killed everyone contracted to it, came from a biological weapon laboratory, and that covering mouth and nose with bare hand is considered as correct coughing ethic. Characteristics that showed statistical significances were education, occupation, and educational/occupational background. Although Indonesian governments already give the best effort to educate the public to stop the transmission, an extensive educational health campaign should be done to raise awareness in public about preventive knowledge and behavior of COVID-19.
\end{abstract}

This is an open access article under the CC BY-SA license.

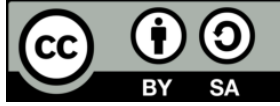

\section{Corresponding Author:}

Rizma Adlia Syakurah

Public Health Faculty

Sriwijaya University, Indonesia

Jl. Raya Palembang-Prabumulih KM. 32 Indralaya, Ogan Ilir, South Sumatra 30862, Indonesia

Email: rizma.syakurah@gmail.com

\section{INTRODUCTION}

For the past 6 months, the world has been rocked with a deadly plague that has come from a new type of corona virus. At the end of December 2019, it was reported that a group of patients were hospitalized with an initial diagnosis of pneumonia but with an unknown etiology. These patients are epidemiologically linked to the wholesale market for seafood and wet animals in Wuhan, Hubei Province, China [1]. This case spread worldwide and on February 11, 2020 WHO announced the official name of this new disease, namely "COVID-19" (Coronavirus Disease 2019) which was listed on the International Classification of Diseases (ICD). On the same day, the International Committee on Taxonomy of Viruses (ICTV) announced the official name of the virus that caused it. The name of the virus, previously known as "2019 novel coronavirus" (n-CoV), now has an official name, "Severe Acute Respiratory Syndrome Coronavirus 2 (SARS-CoV-2) $[2,3]$. 
COVID-19 transmission could be happened by get close contact with sufferers. The highest population in the world such as India shows the confirmed cases on May 30, 2020 were 173,491, with 4.980 deaths related and 82.627 patients have recovered [4]. Indonesia is the fourth most populous country in the world, and thus is predicted to suffer greatly and over a longer time period, when compared to other lesspopulous countries [5]. On June 4, 2020 Indonesia has reached 28,818 persons confirmed COVID-19, 1,721 deaths related to COVID-19 and 8.892 patients have recovered from the disease. Nowadays, on 29 July 2020 as globally COVID-19 has affected in 215 countries with 16.558.289 cases and 656.093 deaths related to COVID-19. While, on 30 July 2020 as much 104,432 persons has confirmed COVID-19 with 4,975 deaths related to COVID-19 and 62,138 have recovered in Indonesia [6, 7]. The Indonesian government has implemented various strategies to prevent COVID-19 transmission. As an initial step on February 29, 2020 Indonesian governments establish that disaster emergency status of COVID-19 was enforced until 29 May 2020. The government works together with mass media to inform how to stop the chain of COVID-19 transmission in Indonesia, such as do physical distancing, work from home, use mask, consume healthy food to increase immunity, and many other preventive behaviors to minimalize the risk [8].

L. Green's theory states that a health behavior is influenced by predisposing factors, enabling factors, and reinforcing factors. One of predisposing factors is demography factors. Demography factors describe differences in age, sex, status, place of origin, occupation and level of education. Demography description will influence the behavior of the community and the outcome of public health [9]. The amount of response and attention of the public regarding the COVID-19 case in Indonesia and the circulation of various information in the community became the basis of interest in identifying and analyzing demography factors with general knowledge on COVID-19.

\section{RESEARCH METHOD}

An observational analytic study with a cross-sectional study was designed for the present study. The population is Indonesian people which internet users. Participants were 1,254 collected through online questionnaire distributed on social media platform, from February 5, 2020 to June 6, 2020. Data were collected using a structured interview method in the form of a closed and open-ended question questionnaire. The questionnaire contains questions that are used to obtain data related to demography and their knowledge about COVID-19 in general and the prevention measure against it, like general description of the SARSCoV-2 virus, symptoms of disease, transmission, risk factors, healing, prevention and danger of COVID-19, and the ethics of coughing and sneezing, mask use, and how to wash hands.

Knowledge will determine from 10 questions about COVID-19 general information and preventive measures, further broke down into 53 answers points. Each points answer will be counted and set in percentage. Any informant score more than $75 \%$ will be categorized as "sufficient" and any less will be considered "insufficient" [10]. The formula used to measure the percentage of answers obtained is:

$$
\text { Percentage }=\frac{\text { Total Score }(0-53)}{\text { Total Option Answer (53) }} \times 100 \%
$$

The data is then processed through the process of checking/validating data, coding, recapitulation, tabulation, and statistical analysis using the IBM SPSS Statistics 24 program. Data analysis used was univariate and bivariate data analysis. Univariate analysis displays frequency distribution and in tabulated form. Bivariate analysis used were the Chi-square hypothesis or independent sample t-test (alternative: Mann-Whitney test) adjusted to the type of variable being analyzed. The results of the analysis in the form of $\mathrm{p}$-value compared with the degree of significance alpha $=0.05$. In addition, this analysis will produce a PR value by using a degree of significance alpha $=0.05$ ( $95 \%$ confidence level/CI).

\section{RESULTS AND DISCUSSION}

As shown in Table 1, age of participants ranged from 12-63 years with average of 22.63 years. Majority of respondents were females $(75.4 \%)$. Half of the participants higher education was university or academy $(55.2 \%)$. Nearly two-thirds of participants were university students $(65.6 \%)$. The educational/occupational background of participants is close to balanced, $48.6 \%$ in the health sector and $51.4 \%$ in the non-health sector. This result is in line with previous study where the majority of respondents are women, almost half are aged 18-29 years, and the majorities are college graduates [11]. These characteristics are consistent with the method of collecting research data conducted using online questionnaires. Based on data from the Indonesian Internet Service Providers Association (APJII) in 2017, 
out of 143.26 million internet users, $49.52 \%$ of them are dominated by millennials, ranging in age from 19 years to 34 years [12]. So this is in line with the most of research respondents, namely the age range of 20 years.

Demography factors that showed statistically significance were education level ( $\mathrm{p}=0.04)$, occupation $(\mathrm{p}=0.002)$ and educational/occupational background $(\mathrm{p}=0,000)$. Statistical tests using Chi Square on educational/occupational background variables resulted in PR 2.154 (PR>1). Individuals with non-health education/work backgrounds tend to have lack of general knowledge about COVID-19 compared to those with health background.

Table 1. Demography characteristics and general knowledge on COVID-19 ( $\mathrm{n}=1,254)$

\begin{tabular}{|c|c|c|c|c|c|c|}
\hline \multirow{3}{*}{ Demography characteristics } & \multicolumn{4}{|c|}{ Knowledge } & \multirow{3}{*}{$\begin{array}{c}\text { PR } \\
\text { CI } 95 \%\end{array}$} & \multirow{3}{*}{$\mathrm{p}$-value } \\
\hline & \multicolumn{2}{|c|}{ Sufficient } & \multicolumn{2}{|c|}{ Insufficient } & & \\
\hline & $\mathrm{n}$ & $\%$ & $\mathrm{n}$ & $\%$ & & \\
\hline Age (mean \pm SD) & \multicolumn{2}{|c|}{$22.4 \pm 5.51$} & \multicolumn{2}{|c|}{$23.29 \pm 7.52$} & - & $0.667^{\wedge}$ \\
\hline \multicolumn{7}{|l|}{ Gender } \\
\hline Male & 238 & 77.27 & 70 & 22.73 & \multirow[t]{2}{*}{$0.946(0.696-1.288)$} & \multirow{2}{*}{$0.726^{*}$} \\
\hline Female & 740 & 78.22 & 206 & 21.77 & & \\
\hline \multicolumn{7}{|l|}{ Education level } \\
\hline No formal education & 1 & 100 & 0 & 0 & \multirow{5}{*}{-} & \multirow{5}{*}{$0.040 * * *$} \\
\hline Elementary school or equivalent & 2 & 66.7 & 1 & 33.3 & & \\
\hline Middle school or equivalent & 10 & 76.9 & 3 & 23.1 & & \\
\hline High school or equivalent & 403 & 73.9 & 142 & 26.1 & & \\
\hline University/ academy & 562 & 81.2 & 130 & 18.7 & & \\
\hline \multicolumn{7}{|l|}{ Occupation } \\
\hline Student & 30 & 65.2 & 16 & 34.8 & \multirow{8}{*}{-} & \multirow{8}{*}{$0.002 * *$} \\
\hline University student & 657 & 79.8 & 166 & 20.2 & & \\
\hline Housewife & 13 & 61.9 & 8 & 38.1 & & \\
\hline Private employees & 103 & 74.6 & 35 & 25.4 & & \\
\hline Entrepreneur & 23 & 9.1 & 15 & 90.9 & & \\
\hline Civil servants & 37 & 69.9 & 16 & 30.1 & & \\
\hline Unemployed & 30 & 88.3 & 4 & 11.7 & & \\
\hline Others & 85 & 84.2 & 16 & 15.8 & & \\
\hline \multicolumn{7}{|l|}{ Educational / occupational background } \\
\hline Health related & 515 & 84.6 & 94 & 15.4 & \multirow[t]{2}{*}{$2.154(1.630-2.846)$} & \multirow[t]{2}{*}{$0.000^{*}$} \\
\hline Non-Health related & 463 & 71.8 & 182 & 28.2 & & \\
\hline
\end{tabular}

This study showed that majority of respondents have sufficient knowledge about COVID-19 in Indonesia. This were related with previous study in Aceh, Indonesia that awareness of and knowledge on the coronavirus was already very high, even though the COVID-19 outbreak was not yet advanced in Aceh at the time of the survey. More than three-quarters of the sample knew about symptoms of the coronavirus and preventive measures against it [13]. Knowledge is influenced by one's experience and the environment which can be expressed and believed to give rise to motivation [14]. This study results highlights the importance of education level, occupation, and health background in having better general knowledge on COVID-19. These three factors influence each other like a vicious circle. The world of work requires education to increase knowledge, understanding or attitudes of workers so they can better adapt to their work environment [15]. Otherwise, knowledge could be obtained through occupation too. People who have jobs will meet more people and exchange information so it will increase knowledge compared to those who do not [16].

This result showed that respondents with higher education level have sufficient of knowledge about COVID-19 (81.2\%). In the previous study, higher education was associated with significantly higher knowledge in preventive behavior and action in illness, and knowledge of COVID-19 transmission routes. Higher education was also associated with higher knowledge on the H1N1 pandemic [12, 17-19]. Education level and background compatibility can affect one's knowledge. Education level will affect the level of acceptance and understanding of an object or material that is manifested in the form of knowledge. The higher the level of education will affect the level of mastery of the material that must be mastered in accordance with the goals and objectives [20]. Higher education teaches people to think more logically and rationally, to be able to see an issue from various sides so they can do more analysis and solve a problem [21]. 
This study found that employment and educational background/work have a significant relationship to knowledge of COVID-19. Individuals with non-health education/work backgrounds have the risk of having bad knowledge two times compared to individuals with educational/health work background. This study in line with the previous, that majority of healthcare workers have good knowledge, a positive attitude and good practice towards COVID-19 [22, 23]. Individual characteristics such as age and gender of the respondents did not have a statistically significant relationship to the knowledge of COVID-19 in this study. This result was different from previous study who found a significant relationship between demography characteristics in the form of gender, age group, marital status, education level, and regional origin of Chinese society to knowledge of COVID-19. The result also found lower knowledge in individuals who unemployed and students compared to individuals who worked as mental labor [24]. Research in Egyptian society also showed significant differences in knowledge based on age and education where respondents who were older and not educated had lower knowledge [10].

Bloom's taxonomic theory that has been revised especially in the cognitive domain by Anderson and Krathwohl divides knowledge into six levels, namely remembering, understanding, applying, analyzing, evaluating, evaluating, and creating (create). This taxonomic concept illustrates higher thought processes at higher levels of knowledge. At the third level in the form of applying, the cognitive process uses a procedure to solve problems [25]. According to Notoatmodjo, knowledge is influenced by one's experience and the environment which can then be expressed and believed to give rise to motivation [26]. Work and educational background / work found is related to the level of knowledge of COVID-19 in this study can be assumed to be in line with the revised Bloom theory and Notoatmodjo. Individuals who have educational/non-health work backgrounds certainly have less knowledge of health experience compared to individuals with educational/health work backgrounds. This is what can make the different levels of knowledge on health issues, especially COVID-19, between these two groups. Individuals with good knowledge can also influence their attitudes and actions in dealing with current situations, it caused by knowledge is a cognitive domain that is very influential in shaping one's actions [24, 27].

COVID-19 which is a world health problem is accompanied by massive fact and issue spread in the community so that WHO uses the word 'infodemic' as a term to refer to information that is surrounded [28]. Due to too much information, the public becomes confused between both. A lot of misinformation regarding COVID-19 can be caused a serious concern that lead to xenophobia [29]. As from this study, fewest participants with low level of education tend to believe that COVID-19 came from a biological weapon laboratory and COVID-19 killed everyone contracted to it. It was disinformation or misinformation. The information circulated from a post on social media Facebook. In fact, the post was a twist from the news by a daily newspaper published in Washington DC, United States, namely The Washington Times, with the title "Virus-hit Wuhan has two laboratories linked to the Chinese bio-warfare program". This news was then translated and rewritten by a number of media. There is no supporting evidence regarding the claim. The Chinese Ministry of Health states that the corona virus originates from the seafood market in Wuhan, as is the second answer option [30].

Another false belief among participants was cover their nose and mouth with the palm of hand when they coughing or sneezing. Belief was obtained from family such as parents and grandparents. Person's belief depends on the strength of the trust handed down by their ancestors and their experience. Socio-cultural belief comes from what they see and what they know. Once belief has been formed it will be the basis of one's knowledge about what can be expected from a particular object. Belief can continue to develop from personal experience, what others say and our own emotional needs are the main determinants in the formation of belief. This generalized personal experience forms a stereotype. If this stereotype has been rooted for a long time, then people will have an attitude that is more based on the predicate attached by the stereotype pattern and not based on a particular attitude object. Attitudes based on stereotyping patterns like this are usually very difficult to accept changes [31]. To make the changes, knowledge and perseverance to continue to practice the behavior is needed. An extensive educational health campaign should be done to raise awareness in public about preventive knowledge and behavior of COVID-19 [32].

The strength of this study lies in its large sample recruited during a critical period and it can prove about significant associations between demography variables towards COVID-19 general knowledge. While the limitations of this study was limited sample representative. Due to limited access on internet and online health information resources, vulnerable populations of Indonesian society under the COVID-19 epidemic such as older adults and rural people at grass-root are hard to reached. Evidenced by the majority of participants were people in the early age of twenty. 


\section{CONCLUSION}

Demography is one of the factors that influence preventive knowledge of Coronavirus Disease 2019 (COVID-19) in Indonesia. Higher education, occupation, and educational/occupational background is the influencing factors. Although Indonesian government already gives the best effort to educate the public to stop the transmission, an extensive educational health campaign should be done to raise awareness in public about preventive knowledge and behavior of COVID-19.

\section{REFERENCES}

[1] I. I. Bogoch, et al., "Pneumonia of unknown aetiology in Wuhan, China: potential for international spread via commercial air travel," Journal of Travel Medicine, vol. 27, no. 2, pp. 1-7, 2020.

[2] World Health Organization, Naming the coronavirus disease (COVID-2019) and the virus that causes it, WHO, 2020. [Online]. Available: https://www.who.int/emergencies/diseases/novel-coronavirus-2019/technicalguidance/naming-the-coronavirus-disease-(covid-2019)-and-the-virus-that-causes-it_Access on 5 June 2020].

[3] A. E. Gorbalenya, et al., "Severe acute respiratory syndrome-related coronavirus: The species and its viruses - a statement of the Coronavirus Study Group," BioRxiv, pp. 1-15, 2020, doi: https://doi.org/10.1101/2020.02.07.937862

[4] W. Bobby, Corona Global Update Saturday, 30 May 2020 Morning: 6 Million Cases in the World, India Becomes the New Epicenter of Asia, Tribunnews.com, 30 Mei 2020. [Online]. Available on: https://palu.tribunnews.com/2020/05/30/update-corona-global-sabtu-30-mei-2020-pagi-6-juta-kasus-di-dunia-indiajadi-episentrum-baru-asia?page $=4$.

[5] ADB, 21 March 2020, ADB approves \$3 million grant to support Indonesia's fight against COVID-19. [Onlnie]. Available: https://www.adb.org/news/adb-approves-3-million-grant-support-indonesias-fight-against-covid-19.

[6] World Health Organization. Coronavirus disease (COVID-19) situation reports, WHO, 2020. [Online]. Available on: https://www.who.int/emergencies/diseases/novel-coronavirus-2019/situation-reports.

[7] Sub Directorate of Emerging Infectious Diseases, The current situation for the development of Coronavirus disease (COVID-19) July 30, 2020, Kemenkes RI, 2020 [Online]. Available: https://covid19.kemkes.go.id/situasi-infeksiemerging/info-corona-virus/situasi-terkini-perkembangan-coronavirus-disease-covid-19-30-juli2020/\#.Xytk7CgzY2w.

[8] COVID-19.go.id, Covid-19 Distribution Map in Indonesia, 2020. [Online]. Available: https://covid19.go.id/petasebaran.

[9] M. J. Gibney, et al., "Public Health Nutrition," Oxford: Blackwell Publishing Ltd, pp. 49, 2008.

[10] S. Arikunto, Research Procedure: A Practical Approach. Jakarta: Rineka Cipta, 2010.

[11] A. S. Abdelhafiz, et al., "Knowledge, perceptions, and attitude of egyptians towards the novel coronavirus disease (COVID-19)," J Community Health, vol. 45, no. 5, pp. 881-890, 2020.

[12] Ministry of Women's Empowerment and Child Protection and Central Statistics Agency. 2018, Thematic Gender Statistics: Profiles of Indonesian Millennial Generation. Jakarta: Kementerian Pemberdayaan Perempuan dan Perlindungan Anak.

[13] Chavarría, E., et al., "Knowing versus doing: Protective health behavior against COVID-19 in Indonesia," Discussion Papers 273, 2020. [Online]. Available: https://www.econstor.eu/handle/10419/219320

[14] S. Karlsson and A. Lindström., Is knowledge enough?: A qualitative study investigating the knowledge-action gap of environmental science students, Bachelor of Science Thesis, Environmental Science Programme, Linköpings Universitet, Sweden, 2020. [Online]. Available: http://urn.kb.se/resolve?urn=urn:nbn:se:liu:diva-167185.

[15] B. Afrilyan, K. Fitri, and M. Marhadi, "The Influence of Competence, Work Experience and Work Placement on the Organizational Commitment of PT. Wahana Meta Riau in Pekanbaru," Jurnal Online Mahasiswa Fakultas Ekonomi Universitas Riau, vol. 4, no. 1, pp. 153-166, 2017.

[16] A. Wawan and M. Dewi, "Theory and Measurement of Human Knowledge, Attitudes, and Behavior/Teori dan Pengukuran Pengetahuan, Sikap, dan Perilaku Manusia,” Yogyakarta: Muha Medika, 2010.

[17] L. L. Lau, et al., "Knowledge, attitudes and practices of COVID-19 among income-poor households in the Philippines: A cross-sectional study," Journal of Global Health, vol. 10, no. 1, pp. 1-11, 2020.

[18] A. W. Tadesse, et al., "Knowledge, Attitude, and Practice and Associated Factors towards COVID-19 among College Students in Amhara Region, Ethiopia; A Cross-Sectional Study," Research Square, 2020.

[19] F. Pagnini, et al., "Knowledge, Concerns, and Behaviors of Individuals During the First Week of the Coronavirus Disease 2019 Pandemic in Italy," JAMA Network Open, vol. 3, no. 7, 2020.

[20] A. Fadhilah, M. Azzuhri, and S. Andarini, "The Effect Of Clarity Of Information And Comfort Of Waiting Room On Satisfaction With Drug Service Through Perception Of Waiting Time," Jurnal Aplikasi Manajemen, vol. 16, no. 2, pp. 205-214, 2018

[21] H. E. Nihayati, E. S. Istizabana, and A. A. Nastiti, "The influence of family psychoeducation to self-awareness family in caring for family members who have mental disorders," EurAsian Journal of BioSciences, vol. 14, pp. $1589-1595,2020$

[22] M. Saqlain, et al., "Knowledge, attitude, practice and perceived barriers among healthcare workers regarding COVID-19: a cross-sectional survey from Pakistan," Journal of Hospital Infection, vol. 105, no. 3, pp. 419-423, 2020. 
[23] G. Huynh, et al., "Knowledge and attitude toward COVID-19 among healthcare workers at District 2 Hospital, Ho Chi Minh City," Asian Pac J Trop Med, vol. 13, no. 6, pp. 260-265, 2020.

[24] B.-L. Zhong, et al., "Knowledge, attitudes, and practices towards COVID-19 among Chinese residents during the rapid rise period of the COVID-19 outbreak: a quick online cross-sectional survey," International Journal of Biological Sciences, vol. 16, no. 10, pp. 1745-1752, 2020.

[25] I. Gunawan and A.R. Palupi, "Bloom's Taxonomy - cognitive revision: a foundation framework for learning, teaching, and assessment/Taksonomi Bloom - Revisi Ranah Kognitif: Kerangka Landasan untuk Pembelajaran, Pengajaran, dan Penilaian," Premiere educandum: jurnal pendidikan dasar dan pembelajaran, vol. 2, no. 02, 2012.

[26] T. R. Aritonang, "The Relationship between Knowledge and Attitudes about Reproductive Health and Premarital Sex Behavior in Adolescents (15-17 Years) at SMK Yadika 13 Tambun, Bekasi/Hubungan Pengetahuan dan Sikap Tentang Kesehatan Reproduksi dengan Perilaku Seks Pranikah pada Remaja Usia (15-17 Tahun) di SMK Yadika 13 Tambun, Bekasi,” Jurnal Ilmiah Widya, vol. 3, no. 2, pp. 61-67, 2015.

[27] J. Moudy and R. Syakurah, "Knowledge related to Coronavirus Disease (COVID-19) Prevention Efforts in Indonesia," HIGEIA (Journal of Public Health Research and Development), vol. 4, no. 3, pp. 333-346, 2020.

[28] World Health Organization, Coronavirus disease 2019 (COVID-19) Situation Report-13, 2020. [Online]. Available: https://www.who.int/docs/default-source/coronaviruse/situation-reports/20200202-sitrep-13-ncovv3.pdf?sfvrsn=195f4010_6.

[29] A. S. Bhagavathula, W. A. Aldhaleei, J. Rahmani, M. A. Mahabadi, and D. K. Bandari, "Novel Coronavirus (COVID-19) Knowledge and Perceptions: A Survey of Healthcare Workers," MedRxiv, pp. 1-15, 2020.

[30] Ministry of Communication and Information of the Republic of Indonesia. [DISINFORMASI] Corona Virus is a Biological Weapon Leaking from the Wuhan Laboratory, January 30, 2020. [Online]. Available: https://kominfo.go.id/content/detail/24076/disinformasi-virus-corona-merupakan-senjata-biologis-yang-bocor-darilaboratorium-wuhan/0/laporan_isu_hoaks.

[31] S. Notoatmodjo, "Health Promotion and Behavioral Sciences," First Edition, Jakarta: Rineka Cipta, 2007.

[32] Fadilah, M., Susanty, M., Samsir, N. I., Trisa, Y., \& Syakurah, R. A., "The influence of online seminars on the knowledge of the general public in the era of the COVID-19 pandemic/ Pengaruh seminar online terhadap pengetahuan masyarakat awam di era pandemik COVID-19," Prosiding Applicable Innovation of Engineering and Science Research, 2020, vol. 1, pp. 280-284. 